\title{
All that you leave behind: the territorial relationship of heritage defence sites and military bases
}

\author{
A. R. Harrington \\ Albany Law School of Union University, USA
}

\begin{abstract}
The decommissioning of military bases is typically difficult and emotional. In the shadows of more evocative issues, such as the potential for job loss at the local level, stands the more nuanced status of the territory on which the military base is located. When a country decides to leave a foreign military base there is a distinct rupture in the territorial relationship. Domestically, however, there are many more complications. At the very practical level, the territorial relationship in the case of heritage defence sites invites a host of legal questions, from complying with the terms of the territorial lease or other property-granting mechanism used by the national government to assume control over the area to strategies for land management, heritage preservation and environmental conservation.

This paper will explore the practical elements of the territorial relationship of defence sites. The goal of this paper is to foster a full understanding of this relationship so that those involved in the planning of defence sites at all levels will understand the many dimensions of this undertaking and how to address them in a positive manner.
\end{abstract}

Keywords: defence sites, redundancy, military bases, environmental impacts, property rights.

\section{Introduction}

The issue of decommissioning or making redundant military bases and defence sites has come to the forefront of military, political and economic practice in recent years. This is so regardless of what side of the Atlantic one is discussing. With both the UK and the USA announcing troop drawdowns and fundamental 
rearrangements of the ways in which their militaries will operate in the future it is imperative that the issue of the territorial relationship of heritage defence sites and military bases be discussed at the legal level. However, this discussion must do more than simply recite the applicable law - rather, it must also take into account the meaning of these laws at the national and local level. Specifically, this discussion must examine the relationship between the territory at issue, the military installation located there and attempts to alter the status of this territory through law and environmental remediation.

This paper addresses such concerns by examining the current regimes used by the UK and the USA in order to decide which heritage defence sites and military bases to make redundant. The paper also discusses the territory-based issues implicated in this designation of redundancy, as in both cases it is impossible for the military to simply walk away from a formerly used site without investing significant time and expense in making the site compliant with applicable environmental and other standards. The current plan of the UK to make domestic bases redundant is in its infancy, however the paper discusses the legal issues that will be faced in order to achieve the realignment of domestic military territorial holdings in the UK. Against this backdrop, the paper will discuss the requirements and practices of the USA, which has experienced five rounds of Base Realignment and Closure (BRAC) commission reports - and their implementation - since 1988. The lessons from these BRAC examples are important in the context of the UK because they highlight the importance of some measures that have already been implemented in both contexts while also illuminating areas in which the UK will need to work in order to effectively implement its redundancy plans and return territory to a civilian-based setting.

\section{Defence sites in the UK}

The issue of defence site redundancy has come to the forefront of British political and military circles in recent years. In part this has been attributable to the global economic downturn, as this resulted in a governmental call for reductions in state spending and the amount of state-owned land across the board. Indeed, given that the Defence Infrastructure Organisation (DIO) - the entity which controls land used by the armed forces in the UK - constitutes one of the largest landholders in the UK itself this is, perhaps, not surprising [1]. However, the redundancy plans also represent a new method of conceiving the overall military status, function and needs of Great Britain and its forces both domestically and overseas [2].

Under newly released policy documents from the Ministry of Defence, it is made clear that the goal of the redundancy plans is at once to strengthen and modernize the British armed forces while also lessening the burden of redundancy declarations on affected communities. As several of the most recent policy documents make clear, there are no defence sites that have been immediately targeted for redundancy designation. Instead, these policy documents suggest that the UK will enter into a potentially BRAC-like process to determine which defence sites should be decommissioned in the future. 


\subsection{General principles of Ministry of Defence landholding}

The legal authority for the military to purchase or otherwise acquire lands within the UK originated in the Military Lands Act of 1892 [3]. This Act set out the ways in which land might be acquired for military purposes, typically through transactions conducted with the Secretary of State. Importantly for the purposes of determining the ability of the current Ministry of Defence to dispose of lands within its control, the Act specified that lands could be leased by the government for military purposes but that, in this situation, the lands would revert to their original leaseholder if the lands ceased to be used for military purposes.

The overall principle of military landholding in the UK asserts that the government will only hold land that is necessary and in-use for military purposes [4]. In the event that land is held by the DIO and not used for military purposes it is the position of the government that the land should be disposed of. When disposing of surplus land, the Ministry of Defence is required to ensure that the disposal comports with all other legal requirements for land transfers and that it be done in a way that encourages economic growth. It is possible for the government to hold lands for military purposes subject to leases, in which case the government typically does not have an ownership interest in the land per se but rather the ability to use the land for a particular time and/or purpose - or freehold title - which can be transferred based on the ownership interests which the government itself possesses. In terms of transferring land, it is possible for the government to convey its interests in land to another governmental entity, to a locality, to a group or to an individual.

The lands held by the Ministry of Defence span the whole of the UK, and are used for all branches of the armed forces. While it is important to note that the Ministry of Defence does also hold a number of lands outside of the UK, and it is likely that some of these holdings will also be declared redundant, they are not within the scope of this paper. Another important point is that there are several forms of redundancy for defence sites. Perhaps the most obvious would be the idea of making an entire military installation redundant, as has happened under the BRAC system in the USA, where entire military bases were decommissioned and closed. However, the Ministry of Defence has also indicated the possibility of retaining a core area within a defence site, and even an area which is likely to have future military uses in support of the core defence site, while at the same time acknowledging an area of the current defence site that is not needed for military purposes according to current or future estimates. In this situation, it would then be preferable that the Ministry of Defence declare this unnecessary area to be redundant and make it available for other, non-military uses. Another possibility, again mirroring some of the BRAC practices in the USA, is to consolidate several defence sites with similar functions into a larger defence site, thereby minimizing the amount of land needed while, theoretically, maximizing efficiency. 


\subsection{Requirements for redundant defence sites in the UK}

In its most recent statements, the Ministry of Defence and the British government have enunciated a policy of careful deliberation in all questions of redundancy for defence sites within the UK [1]. The Ministry of Defence has also stressed that, although there are overall principles to be applied in the decision-making process, each defence site will be analysed at the individual level to determine the necessity of redundancy and the impacts that this designation would have. Where a decision to divest any defence site interest is made, the Ministry of Defence has made a commitment to engage with the local community and government in order to facilitate the transition of the land and those who will be impacted by the decision. This reflects the reality that closing any defence site will necessarily have negative impacts on at least some segment of the population and the economic base existing near the defence site. As in the USA, the Ministry of Defence and the government have stated a commitment to assist localities in finding new economic avenues post-redundancy.

The close relationship between the Ministry of Defence and the localities does not, however, mean that the Ministry of Defence intends to vest the localities with the ultimate decision-making authority as to the approved uses of the land to be made redundant. Rather, the Ministry of Defence anticipates that it will designate the uses for these lands after consultation with the localities involved.

A key concern for transferring any lands associated with defence sites is their environmental status and the need to bring this status into conformity with local and national requirements. This reflects the many potential impacts that military and military-associated activities can have on land, ranging from chemical contamination to the presence of unexploded ordnances. As an established matter of law and policy, the Ministry of Defence complies with applicable environmental standards laws within the UK and is committed to conducting Land Quality Assessments on defence sites even when the possibility of making some of these sites redundant is not an issue [6].

The standard procedure for remediation in these circumstances centers on the Ministry of Defence taking the necessary steps for remediation and then certifying that the land in question has been properly remediated. The extent of remediation necessary is dependent on a variety of factors and the classification of the land in question on a scale of possible categories of contamination. This applies regardless of the Ministry of Defence's intent to sell or otherwise alienate the land from the Ministry of Defence's holdings.

There is another way that the Ministry of Defence has indicated that it will address remediation issues, namely in the form of clawback terms in the deeds of sale for land [7]. By using clawback terms, the seller and the buyer of the land here the Ministry of Defence and the purchaser of the land - agree that the land will need some remediation and set a threshold amount up to which the Ministry of Defence agrees to compensate the purchaser for necessary remediation costs. Typically, this will result in a lower initial purchase price for the buyer due to the environmental risks involved. 
Once the decision to make a particular defence site - or portion thereof redundant is made, and the environmental status of the defence site has been determined, the Ministry of Defence is required under the Crichel Down Rules to investigate the ownership history of the land in question [8]. The Crichel Down Rules have become somewhat complex since their post-World War II origins, however the essential requirement has remained the same - where the British government compelled a landholder to allow the government to use his land for a governmental purpose, and the government later ceases using the land for a governmental use, it must be offered back to the original landowner before any other transfer or sale can be made. There are some exceptions to this rule, for example where the heirs to the original landholder cannot be found or where the character of the land has "materially changed" since the government held it. Regardless of these exceptions, it is necessary for the Ministry of Defence to make a determination as to whether the Crichel Down Rules would apply and, if so, to take the proper steps to ensure compliance with them.

\subsection{Summary}

Thus, while there have been instances of defence sites being sold or transferred in the past, it is clear that, in the context of the UK, larger scale determinations of redundancy are likely to occur in the immediate future. An examination of the existing legal requirements for transferring redundant defence sites shows that there are essential considerations which must be taken into account by the Ministry of Defence - namely the status of the Ministry of Defence's tenure to the land itself, the environmental situation on and in the land itself, and the type of sale or transfer to be effected - as well as the inherently political questions of economic and social impacts on the communities that surround the targeted defence sites.

\section{Base closures in the USA}

While there has been much recent publicity regarding the drawdown of the USA military and the priority shift in its military policy, the practice of closing and realigning military bases is not new [9]. Indeed, since the end of the Cold War, the USA has systematically re-examined and altered the location and size of its military installations at home and abroad. In order to accomplish this, a series of BRAC rounds were required as a matter of federal law - the purpose of each round was to study the needs of the military against its assets and to determine ways in which these two interests could be consolidated.

These practices have been far from uncontroversial, and indeed there have been fundamental disagreements between the Department of Defense and the BRAC committees regarding the closure of military bases. However, what is notable is that these BRAC rounds have been successfully implemented and earlier rounds served as models for later rounds. This is particularly important in the case of the last - fifth - BRAC round, in which the authorizing legislation greatly expanded the scope of factors to be evaluated in making a base closing 
determination, including a greater focus on economic and environmental impacts of any action [10].

\subsection{General principles of federal landholding for military purposes}

Under the USA Constitution, military spending authorization is a reserved power of Congress, and typically very few have challenged the acquisitions of the USA military [11]. This trend has been eroded in recent years, as even Congress has proved interested in greater scrutiny of military spending, including spending on military bases and installations. The early principles underlying the first BRAC rounds centered on the idea that the extent of federal landholding for military purposes had become outdated and did not address the modern military need of the USA armed forces. Various BRAC commission reports have highlighted the fact that military lands within the USA are comprised of multifaceted entities, containing everything from training centers to hospital facilities to quarters for troops and dependents. As such, the decision to close a military base in whole or in part often includes a requirement that such facilities be relocated or merged with other facilities in order to achieve maximum effectiveness.

When military land has been targeted for closure, the Department of Defense will first seek to transfer the land to another federal agency unless the land has in fact been leased by the Department of Defense rather than acquired outright. In the event of a lease then the terms of the lease must be scrutinized in order to determine the ramifications of and ability to terminate or alter the lease terms. After this, the Department of Defense will then offer any remaining land to state or local authorities for development projects, and ultimately will, if appropriate, offer the land for sale to private purchasers [12]. Throughout the process of transferring military bases and associated land there is a general requirement that the Department of Defense involve local actors even if the land in question is not to be transferred directly to the locality.

\subsection{Requirements for base closings in the USA}

The BRAC committees established through each BRAC round legislation were tasked with evaluating the status of military bases and installations throughout the USA in order to determine which bases should be targeted for closure or realignment. Throughout this process, the BRAC committees were subject to input from the Department of Defense and other critical actors. Once the decision to close a military base was made under these rounds the closure did not take effect immediately. Instead, a series of considerations regarding the appropriate type of property transfer, assistance to the local community, and environmental requirements were needed. These requirements were undertaken by the Department of Defense, working with the appropriate branch of the military.

Community consultation and assistance at the federal and state level has been and continues to be crucial for the communities that surround military bases which are closed or partially realigned [13]. As many statistics highlight, and contrary to some vocal concerns, these communities often fare better 
economically in the long-term than they would have had the base continued to function, although the short-term impacts of base closures are economically damaging [14]. Thus, the importance of national and local support to these communities can be highlighted as critical. This is particularly so where the federal authorities have encouraged an alternate use for an existing base facility, such as the conversion of a military airfield facility into a civilian airport.

The USA has become increasingly concerned with environmental pollution and environmental protection and these concerns have been translated into a number of federal laws that have been applied to military bases. The same wide range of potential contaminants discussed in the context of the UK are of concern in the USA and this concern is reflected in the terms of federal environmental laws. Key among these laws are the Clean Air Act, the Clear Water Act, the Comprehensive Environmental Response, Compensation and Liability Act ("CERCLA"), and the National Environmental Policy Act ("NEPA"), as well as laws regarding the preservation of national heritage sites. These laws, particularly CERCLA, require that the landholder, including the Department of Defense, engage in acts of remediation to clean the land in question to established federal standards prior to the transfer of the land to another individual [15]. In order to properly implement the requisite cleanup procedures and fulfil statutory and regulatory, the Department of Defense invested more time and effort than initially anticipated, meaning that the Department of Defense has not been able to successfully meet many target dates for divesting itself of lands to be closed. In some limited circumstances it is possible for the Department of Defense to engage in an "early transfer" of the contaminated land to a buyer who will complete the requisite remediation. In some instances, the Department of Defense has created leases which allow interested governmental or other entities to take possession of the lands prior to their full remediation in order to allow continued use of the lands and generation of economic benefits for the surrounding community. Regardless of the conveyance used, however, the obligation for decommissioned military facilities to meet remediation requirements at the federal level - and, where appropriate, the state level as well - remains with the Department of Defense.

\subsection{Summary}

The USA has an entrenched system of assessing the needs for military base closures and realignment, although this system has never been without controversy. Indeed, simply because the BRAC committee recommended the closure of a military base was not a guarantee that the base would be closed quickly because of the myriad issues that remained to be addressed by the Department of Defense.

With the last BRAC round - the 2005 BRAC round - closed, it is uncertain whether there will be additional base closures in the USA. However, the lessons of the USA base closure experience - in terms of process for arriving at a decision as to which bases to close and implementation of this decision - are important for future base closings in both the USA and the UK. 


\section{Conclusion}

The above paper has presented an overview of the issue of redundancy/closing of defence sites and military bases in the UK and the USA. It has demonstrated that this is an inherently political process and one that, by its very nature, should be expected to involve individual and community emotion as well.

In addition, this paper has shown the importance of the relationship between the territory on which a defence site/military base is located and the ability of the state to effectively make that site redundant. With the exception of the final BRAC round, the considerations that the BRAC committee was statutorily required to undertake did not center on the physical state of the territory in terms of its environmental status. Thus, the desirability of closing a military base in the USA was not, until the 2005 BRAC round, judged as critically by the relationship between it and the territory on which it was located, although as a matter of law the Department of Defense was left to address the repercussions of the physical state of the territory in its remediation plans. The legislation authorizing each BRAC round did consistently require that the reintegration of the territory on which the military base was located be addressed. However, the reintegration of this territory was ultimately dependent on the ability of the Department of Defense and the appropriate branch of the military engaging in the necessary remediation processes for that particular piece of territory.

Overall, the lesson that can be taken from the American experience is that it is necessary to evaluate all aspects of territoriality when making the decision as to which defence sites to make redundant. This lesson highlights the fact that political, legal, economic and environmental issues are ultimately tied together in this content. This serves as a valuable lesson to the UK as it begins its plan to modernize its military apparatus and, as a consequence, make certain defence sites redundant.

\section{References}

[1] Ministry of Defence, Defence Infrastructure Interim Land and Property Disposal Strategy, October 2011.

[2] Her Majesty's Government, Securing Britain in an Age of Uncertainty: The Strategic Defence and Security Review, October 2010.

[3] Military Land Act of 1892.

[4] Ministry of Defence, Defence Infrastructure Interim Land and Property Disposal Strategy, October 2011.

[5] Her Majesty's Government, Securing Britain in an Age of Uncertainty: The Strategic Defence and Security Review, October 2010.

[6] Defence Estates, Practitioner Guide: Contaminated Land Management: Land Quality Assessment (LQA) Management Guide, 7 April 2011.

[7] Secretary of State for Defence, Conditions of Sale and Form of Tender: Ministry of Defence Clawback and Overage Provisions, 2009.

[8] Office of the Deputy Prime Minister, Circular: Compulsory Purchase and the Crichel Down Rules, 31 October 2004. 
[9] Department of Defense, Report Required by Section 2912 of the Defense Base Closure and Realignment Act of 1990, as amended through National Defense Authorization Act for Fiscal Year 2003, March 2004.

[10] Office of the Under Secretary of Defense (Installations and Environment), Base Redevelopment and Realignment Manual, 1 March 2006.

[11] Rubenson, David, Weissler, Robert, Wang, Carolyn and Everson, Robert, Does the Army Have a National Land Use Strategy? Rand: Santa Monica, CA, 1999.

[12] USA General Accounting Office, Military Base Closures: Progress in Completing Actions from Prior Realignments and Closures, April 2002.

[13] USA General Accounting Office, Military Base Closures: Assessment of DOD's 2004 Report on the Need for a Base Realignment and Closure Round, May 2004.

[14] Cowan, Tadlock and Gonzales, Oscar R., Military Base Closures: Socioeconomic Impacts, Congressional Research Service, Washington, D.C., 25 January 2010.

[15] Office of the Under Secretary of Defense (Installations and Environment), Base Redevelopment and Realignment Manual, 1 March 2006. 